JURNAL RESPIRASI

JR

Vol. 5 No. 3 September 2019

\title{
Lobektomi Life Saving pada Hemoptisis Berulang Pada Tuberkulosis Paru
}

\author{
Soedarsono $^{1 *}$, Tri Puji Astuti ${ }^{2}$ \\ ${ }^{1}$ Departemen Pulmonologi dan Ilmu Kedokteran Respirasi, Fakultas Kedokteran, Universitas Airlangga/RSUD Dr. Soetomo, \\ Surabaya, Indonesia \\ 2 RSUD Dr. H. Moch. Ansari Saleh Ansari Saleh, Banjarmasin, Indonesia
}

\begin{abstract}
Background. Hemoptysis is the most common complication of lung tuberculosis (TB). Its can occur repeated and massive. Reccurent massive hemoptysis resolved with conservative therapy but if conservative therapy fails, definitive therapies such as lobectomy surgery are used as alternative treatments especially life-threatening. Case. A 38-year-old man with chief complaint hemoptysis since 4 months pior to admission hospital. Hemoptysis 4-5 times daily with volume 200-600 cc per day and make him shortness of breath and anemia. Initial AFB (Acid Fast Bacilli) was positive and GeneXpert MTB (+) sensitive rifampisin. He got Anti Tuberculosis Drug (ATD) therapy 1st category since 3 months ago. He has been given conservative therapy for hemoptysis but failed. Discussion. Surgery is one of alternative therapy for reccurent massive hemoptysis. Surgery only if source of bleeding already known certainty. In this case patient were suggest for lobectomy superior right lung lobe, not a segmentectomy because there was adhesions on intrathoracic. After lobectomy he getting better and hemoptysis stops. He has continued ATD until 6 months without hemoptysis. Conclusion. Reccurent massive hemoptysis and life-threatening with failure of conservative therapy may given definitive therapy such as lobectomy.
\end{abstract}

Keywords: Lobectomy, Massive hemoptysis, Pulmonary Tuberculosis

Correspondence: Soedarsono, Departemen Pulmonologi dan Ilmu Kedokteran Respirasi, Fakultas Kedokteran Universitas Airlangga/RSUD Dr. Soetomo. Jl. Mayjen. Prof. Dr. Moestopo 6-8 Surabaya 60286. E-mail: ssoedarsono@ gmail.com

\section{PENDAHULUAN}

Tuberkulosis merupakan salah satu penyakit menular mematikan dan sampai saat ini masih menjadi perhatian masyarakat dunia. Berdasarkan laporan World Health Organization (WHO) pada tahun 2018 sekitar 9 juta orang menderita tuberkulosis dan 1,5 juta diantaranya meninggal dunia. Tahun 2018 diestimasikan 9 juta orang didunia menderita tuberkulosis, dan lebih 56\% tersebar di Asia Tenggara dan Pasifik Barat. Pada tahun yang sama Indonesia masuk dalam negara dengan beban tinggi tuberkulosis dengan menduduki peringkat ke-4 sebagai negara penyumbang penyakit tuberkulosis setelah India, Cina, dan Afrika Selatan. ${ }^{1}$

Prevalensi tuberkulosis di Indonesia pada tahun 2013 sebesar 272 per 100.000 penduduk dan angka insiden sebesar 153 per 100.000 penduduk dengan jumlah kematian akibat tuberkulosis sebesar 25 per 100.000 penduduk. Jumlah kasus tuberkulosis baru BTA positif pada tahun 2011-2014 di Provinsi Jawa Timur cenderung mengalami penurunan. Pada tahun 2014 jumlah kasus tuberkulosis baru BTA positif di Provinsi Jawa Timur sebanyak 21.036 orang menurun dari jumlah kasus baru BTA positif tahun 2013. Jumlah kasus tuberkulosis baru BTA positif di Provinsi Jawa Timur sebagian besar terjadi pada penduduk usia produktif antara usia 15 tahun hingga 65 tahun dan sebagian lagi menyerang anak-anak usia kurang dari 15 tahun $^{2}$

Salah satu komplikasi dari TB paru adalah batuk darah atau hemoptisis. Hemoptisis masif sering terjadi pada pasien dengan TB paru. Batuk darah masif dapat diklasifikasikan berdasarkan volume darah yang dikeluarkan pada periode tertentu. Batuk darah masif memerlukan penanganan segera karena dapat mengganggu pertukaran gas di paru dan dapat mengganggu kestabilan hemodinamik penderita sehingga bila tidak ditangani dengan baik dapat mengancam jiwa. ${ }^{1}$

Berikut akan dipaparkan laporan kasus penderita TB paru dalam pengobatan kategori I dengan komplikasi hemoptisis masif berulang dan gagal pengobatan dengan konservatif kemudian dilakukan pembedahan untuk mengatasi hemoptisis berulan, sebagai upaya life saving dan perbaikan kualitas hidup penderita. 


\section{KASUS}

Seorang laki-laki 36 tahun datang ke Instalasi Gawat Darurat RSUD Dr. Soetomo dengan keluhan utama batuk darah darah kurang lebih 5 bulan terakhir \pm 50 -100 cc per hari, tidak terdapat sesak napas. Pasien demam naik turun, terdapat keringat malam. Penurunan nafsu makan dan penurunan berat badan.

Riwayat pengobatan OAT selama 6 bulan tahun 2005 dan pasien dinyatakan sembuh. Pemeriksaan BTA awal 3+ dan tidak ada pemeriksaan BTA pada akhir pengobatan. Riwayat rawat inap di RS. Dr. Soetomo pada bulan April, Mei, Juni 2017 dengan keluhan batuk darah berulang dan TB paru dalam terapi kategori I fase lanjutan dengan 3 tablet 2 FDC. Riwayat pemberian obat Codein $3 \times 10 \mathrm{mg}$ dan Asam Tranexamat tablet 3x $500 \mathrm{mg}$. Riwayat asma, kencing manis dan hipertensi tidak ada.

Pada pemeriksaan paru, inspeksi dan palpasi simetris, fremitus raba kanan menurun, perkusi sonor pada kedua thoraks kanan dan kiri, auskultasi vesikuler menurun 1/3 thoraks kanan, terdengar ronkhi hemitoraks kanan, tidak wheezing.

Pemeriksaan CT Scan tampak "tree in bud appearance" di segmen anterior lobus superior paru kanan dan segmen superior lobus inferior paru kanan. tampak ground glass opacity di sehmen anterior lobus superior paru kanan, segmen superior lobus inferior paru kanan, segmen lateral basal lobus inferior paru kanan, segmen medial basal lobus inferior paru kanan dan segmen apicoposterior lobus superior paru kiri. Tampak multiple cavitas di segmen anterobasal lobus inferior paru kanan. Tampak fibrosis dengan traction bronchiectasis di segmen apical lobus superior paru kanan, segmen superior lobus inferior paru kiri, segmen superior lobus inferior paru kanan dan segmen apicoposterior lobus superior paru kiri. Tampak fibrosis dengan septal thickening di segmen medial basal lobus inferior paru kanan. Tampak paraseptal emphysema di segmen apical dan posterior lobus superior paru kanan, segmen apicoposterior lobus superior paru kiri, segmen superior lobus inferior paru kanan. Tampak hilus kanan teertarik ke superior disertai penebelan pleura kanan atas. Kesimpulan mengarah pada TB paru dengan tanda-tanda infeksi aktif.
Pemeriksaan Bronkoskopi FOB terdapat perdarahan aktif, blood streak dari segmen B2 (lobus paru kanan). Hasil Smear dan Kultur BAL dekstra tanggal 11 Juli 2017 ditemukan bentukan kuman batang gram. Pada Kultur BAL Sinistra ditemukan bentukan kuman batang gram negative $1+$, normal respiratory flora 1+ dengan backround PMN 2+, epithel 1+.

Hasil konsultasi bedah thoraks dan kardiovaskular disarankan untuk dilakukan tindakan pembedahan segmentektomi paru kanan sebagai terapi invasif pada pasien ini. Keputusan tersebut diambil dengan beberapa alasan:

- Pasien memiliki riwayat hemoptisis yang masif dan berulang

- Hasil pemeriksaan penunjang dari hasil FOB yang menunjukan adanya perdarahan aktif di segmen B2 lobus superior paru kanan dan dari hasil CT scan thorax dengan kontras menunjukan adanya multiple giant bullae lobus superior paru kanan.

- Memperbaiki kualitas hidup penderita.

Persiapan sebelum tindakan bedah pasien dilakukan uji Fungsi paru untuk menilai komplikasi setelah pasca operasi dengan hasil sebagai berikut:

Dilakukan operasi thoraks pada tangga 24 Agustus 2017, pada awalnya operasi direncanakaan pembedahan dengan cara segmentektomi pada segmen B2 paru kanan. Pada saat durante operasi terdapat perlengketan luas pada lobus superior kanan kemudian diputuskan untuk mengambil satu lobus superior kanan pada pasien ini. Perlengketan paru lobus superior kanan dengan dinding thoraks dan terdapat multiple bullae di lobus superior kanan.
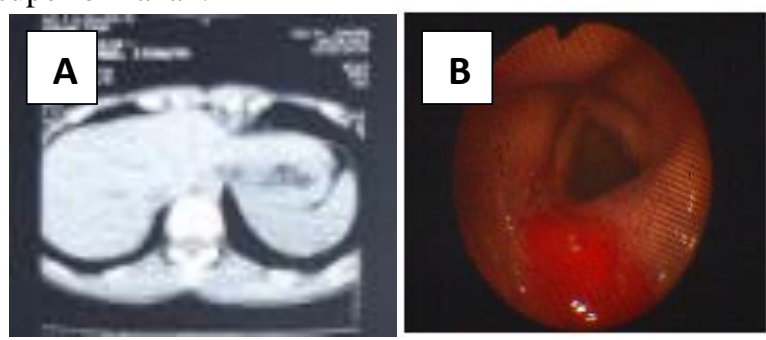

Gambar 1

a. Ct scan thoraks + kontras tanggal 11 Juni 2017 b. FOB tanggal 11 Juli 2017
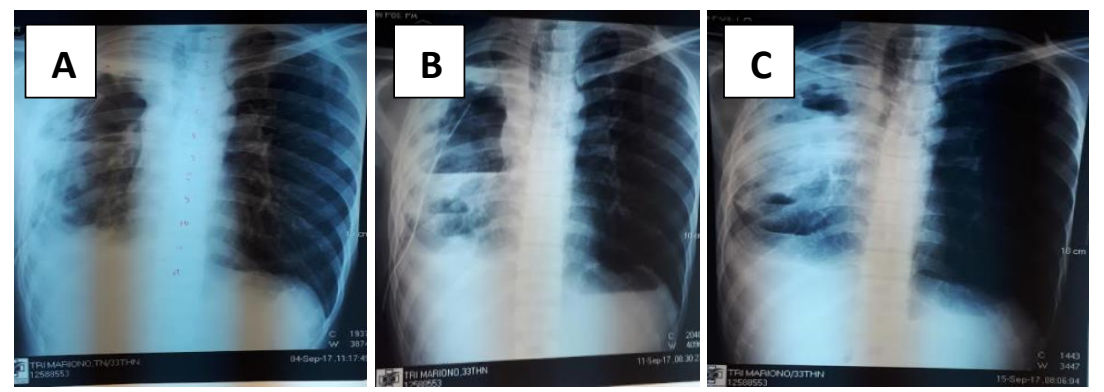

Gambar 3. A). Hasil rontgen 4 september 2017; B). Foto thoraks evaluasi 11 September 2017; C). Foto thoraks setelah chest tube dilepas 


\section{PEMBAHASAN}

TB Paru merupakan penyebab paling sering terjadi hemoptisis di negara berkembang seperti di Indonesia. Selain itu bisa juga disebabkan bronkiektasis, kanker paru dan bronkitis sebagai penyebab terbanyak selanjutnya. Hemoptisis dapat terjadi pada TB aktif (lesi kavitas, ruptur aneurisma arteri pulmonalis) atau sebagai sekuele TB. ${ }^{3}$

Hemoptisis adalah ekspektorasi darah atau dahak bercampur darah yang berasal dari saluran napas bawah dan parenkim paru. Sumber perdarahan dari saluran napas atas bukan saluran napas bawah dan parenkim. Hemoptisis dapat sembuh sendiri tetapi kurang dari 5\% dapat menjadi berat atau masif bahkan kematian ${ }^{1}$

\section{Patogenesis Hemoptisis}

Arteri bronkial adalah penyebab utama perdarahan pada kebanyakan pasien dengan hemoptisis. Pada penderita tuberkulosis, terjadi erosi dari 'aneurisma Rasmussen', (dilatasi paru cabang arteri karena peradangan kronis) juga dapat menyebabkan hemoptisis. Peradangan kronis dinding bronkus pada tuberkulosis menyebabkan kerusakan dan menyebabkan perdarahan arteri bronkial. Tekanan arteri pulmonalis, yang tinggi juga dapat terjadi perdarahan berat dan sulit dikendalikan. ${ }^{7}$ Kavitas pada TB paru yang terdapat pada pleura parietal dan dada dinding, erosi arteri interkostal subklavia atau arteri mamaria juga dikaitkan dengan hemoptisis. Kavitas TB paru memiliki aneurisma arteri kecil (aneurisma Rasmussen) di paru yang bisa pecah dan menyebabkan hemoptisis masif. ${ }^{7,8}$

Aneurisma Rasmussen adalah suatu komplikasi TB paru yang merupakan suatu aneurisma arteri pulmonalis di sekitar atau dalam kavitas TB. Terbentuknya aneurisma Rasmussen disebabkan oleh kelemahan progresif dinding arteri pulmonalis pada kavitas TB yang terjadi seiring pergantian lapisan media dan adventitia dinding vaskular oleh jaringan granulasi. Lapisan tersebut secara perlahan akan digantikan oleh fibrin. Hal ini menyebabkan penipisan dinding arteri, pembentukan pseudoaneurisma, dan perdarahan akibat ruptur. $^{8}$

Pasien pada kasus ini mengalami komplikasi TB paru yaitu hemoptisis yang berulang dalam jangka waktu yang berdekatan. Setiap batuk mengeluarkan darah kurang lebih setengah gelas aqua dan dapat berulang beberapa kali dalam 1 hari. Pasien beberapa kali diberikan perawatan rawat inap untuk mengatasi keluhan tersebut dengan diberikan terapi konvensional.

Definisi hemoptysis atau hemoptisis mayor dan masif mungkin berbeda di dalam beberapa literatur. Ekspektasinya, jika hemoptisis darah yang keluar antara
$200 \mathrm{ml}$ sampai $600 \mathrm{~mL}$ darah dalam sehari didefinisikan sebagai haemoptysis "mayor" sedangkan jumlah di atas itu dikenal sebagai haemoptoe "masif" Hemoptisis masif adalah:

1. Batuk darah > $600 \mathrm{cc} / 24$ jam dan dalam pengamatan batuk darah tidak berhenti.

2. Batuk darah $250-600 \mathrm{cc} / 24 \mathrm{jam}, \mathrm{Hb}<10 \mathrm{gr} \%$ dan batuk darah berlangsungterus.

3. Batuk darah $250-600 \mathrm{cc} / 24 \mathrm{jam}, \mathrm{Hb}>10 \mathrm{gr} \%$ dan dalam. pengamatan 48 jam perdarahan tidak berhenti ${ }^{8}$

Terkadang, jumlah perdarahan sedikit tapi memyebabkan keterbatasan fungsi pernapasan pada pasien yang bisa menyebabkan sumbatan pernapasan dan mengancam nyawa. Hemoptisis masif tidak hanya terkait dengan jumlah darah yang keluar tetapi juga untuk risiko terjadinya aspirasi. ${ }^{7}$

Bahaya hemoptisis masif yang sering dijumpai dan dapat membahayakan penderita:

1. Terjadinya asfiksia oleh karena terdapatnya bekuan darah dalam saluran pernapasan

2. Jumlah darah yang dikeluarkan selama terjadinya hemoptisis dapat menimbulkan renjatan hipovolemik

3. Aspirasi

\section{Penanganan hemoptisis masif}

1. Penanganan non invasif

Tujuan pengelolaan pasien dengan hemoptisis ada tiga hal: menghentikan perdarahan, mencegah aspirasi, dan mengobati penyebab yang mendasari. Evaluasi dari "ABC" (yaitu, jalan nafas, pernapasan, dan sirkulasi) adalah langkah awal. ${ }^{9,10}$

a. Menenangkan penderita dan memberitahu penderita agar jangan takut untuk membatukkan darahnya

b. Penderita diminta berbaring pada posisi bagian paru yang sakit atau sedikit trendelenburg, terutama bila refleks batuknya tidak adekuat

c. Jaga agar jalan napas tetap terbuka. Bila terdapat tanda-tanda surnbatan jalan napas perlu dilakukan pengisapan atau bila diperlukan dilakukan pemasangan pipa endotrakeal. Pemberian oksigen hanya berarti bila jalan napas bebas hambatan atau sumbatan

d. Pemasangan IV line untuk penggantian cairan maupun untuk jalur pemberian obat parenteral

e. Pemberian obat hemostatik belum jelas manfaatnya pada batuk darah yang tidak disertai kelainan faal hemostatik 
f. Pemberian anti-tusif tidak disarankan karena dapat menghambat batuk sebagai mekanisme pertahanan tubuh untuk mengeluarkan darah. Vitamin K dapat diberikan untuk mengkoreksi koagulopati.

g. Jika perlu, pasang ETT dan bila gagal napas, maka lakukan pemasangan ventilasi mekanik

2. Bronchial Artery Embolization (BAE)

BAE adalah suatu prosedur non bedah untuk mengatasi hemoptisis yang masif. BAE pertama kali diperkenalkan oleh Remy pada tahun 1973. Sejak saat itu, tindakan BAE diyakini keamanan dan efektivitasnya dalam mengendalikan hemoptisis di paru dengan beragam penyebab. ${ }^{10}$

BAE menggunakan Computed Tomografi (CT), Angiografi paru atau bronkoskopi untuk melacak lokasi perdarahan di paru. Sebelum melakukan tindakan BAE, evaluasi suplai arteri bronkial dan non bronkial sangat penting untuk menghindari embolisasi arteri yang lain. Mikrokateter digunakan untuk menghindari embolisasi non-target. ${ }^{10}$

Autogram menggunakan kateter pigtail thoracic dengan ukuran 5 atau 4 F. Bahan embolisasi yang paling umum digunakan adalah partikel gelatin (gelfoam) dan partikel polivinil alkohol (PVA). Gelfoam menjadi bahan embolisasi yang bersifat sementara dan angka kekambuhannya tinggi dibanding PVA. Partikel PVA bersifat permanen sebagai bahan embolisasi. Ukuran partikel yang biasa digunakan di BAE adalah 300500mikron. ${ }^{10,11}$

BAE sangat efektif dalam mengendalikan hemoptisis akut sekitar 73-98\% tanpa kekambuhan. Kateterisasi yang selektif dan komplit embolisasi berpengaruh terhadap tingkat keberhasilan. 10-52\% tingkat kekambuhan tergantung pada beberapa faktor termasuk kondisi penyakit primer dan ketepatan prosedur. ${ }^{10,11}$

Komplikasi tindakan BAE ini yang paling sering dikeluhkan adalah nyeri dada. Disfagia bisa terjadi pada embolisasi cabang esophagus dan biasanya sembuh dengan sendirinya. Komplikasi yang jarang terjadi pada BAE meliputi fistula bronchoesophageal, nekrosis bronkial, infark paru dan perikarditis. ${ }^{12}$

Pasien ini diberikan pengobatan kovensional untuk mengatasi hemoptisis masif berulangnya yag terdiri dari pemberian cairan, antitusif, obat anti hemostasis dan pasien juga dianjurkan pada posisi tendelenberg tapi keluhan belum teratasi. Pasien dikonsulkan ke bedah thoraks kardiovaskular dan disarankan terapi definitif yaitu dengan pembedahan.

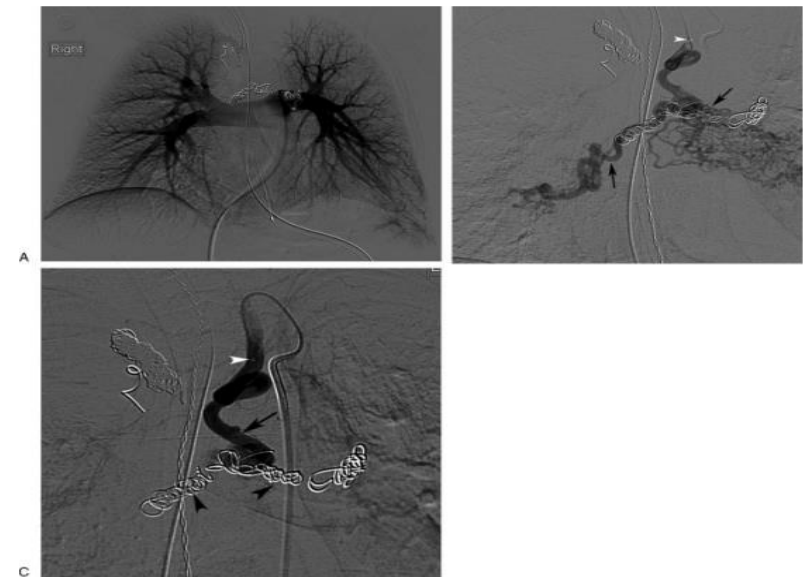

Gambar 4. Bronchial Artery Embolization dengan mikrokateter

3. Penanganan Definitif

Terapi definitif hemoptisis masif adalah pembedahan. Tindakan bedah dilakukan bila pasien memenuhi persyaratan sebagai berikut:

a. Sudah diketahui jelas sumber perdarahan,

b. Tidak ada kontra indikasi medik,

c. Setelah dilakukan pembedahan sisa paru masih mempunyai fungsi yang adekuat (faal paru adekuat) Pasien bersedia dilakukan tindakan bedah. 11,12

Literatur lain menyebutkan Indikasi pembedahan pada tuberkulosis paru menurut Amiratta et al lebih mengutamakan adanya resiko timbul aspirasi dibanding dengan jumlah darah yang dibatukkan. Dalam hal tersebut ditekankan pendekatan pembedahan agresif yang mempunyai prognosis/angka penyelamatan lebih baik dari pada pengobatan medis. ${ }^{13}$

Indikasi relatip meliputi penderita sudah diobati dan sputum sudah negatif tetapi tetap mempunyai keluhan keluhan, misalnya:

1. batuk darah masif dan berulang.

2. Batuk dengan banyak sputum. kerusakan satu paru atau lobus yang sering menimbulkan keluhan dan dikhawatirkan penyakitnya akan kambuh.

Intervensi bedah memiliki mortalitas $\pm 18 \%$ bila dilakukan elektif dan meningkat hingga $40 \%$ bila dilakukan dalam keadaan darurat. Tindakan konservatif seperti observasi dan obat-obatan juga meningkatkan angka mortalitas hingga $50 \% .^{14}$

Kontraindikasi suatu reseksi paru adalah:

1. Reseksi bilateral.

2. penyakit paru progresif.

3. ketidakmampuan untuk menemukan lokasi pendarahan; 
4. karsinoma paru yang tidak bisa dioperasi

5. penurunan fungsi paru berat.

6. Pasien dengan koagulopati

7. Faal paru penderita jelek

Syarat prabedah mempunyai beberapa tujuan antara lain: 8,9

1. Menentukan nilai faal paru prabedah paru, untuk menentukan apakah penderita berada pada kondisi resiko tinggi timbulnya komplikasi pasca bedah.

2. Pada penderita yang akan mengalami reseksi paru (segmenektomi, lobektomi, atau pneumonektomi), nilai faal paru prabedah penting diketahui, karena dapat dipakai untuk meramal/ menentukan berapakah nilai faal paru yang tersisa pasca bedah. Dengan lain perkataan bahwa nilai Faal paru prabedah dipakai untuk mengetahui toleransi paru penderita sesudah pembedahan

3. Nilai faal paru prabedah dipakai untuk menentukan toleransi pemafasan penderita terhadap tindakan bronkoskopi, bedah toraks lainnya di luar paru.

4. Dengan rnengetahui nilai faal paru prabedah dapat pula dipakai untuk membantu rnenentukan jenis anestesi atau obat anestesi yang spesifik untuk penderita calon bedah yang dihadapi, dan dapat pula dipakai untuk menentukan terapi respirasi chest physiotherapy yang perlu dilakukan terhadap penderita calon bedah sebelurn pernbedahan dapat dilaksanakan

Pasien dilakukan terapi definif yaitu pengangkatan segmentektomi lobus superior paru kanan. Pada durante operasi diapatkan perlengketan yang luas dan multiple bulla dilobus superior kanan paru sehingga diputuskan untuk melakukan lobektomi lobus superior paru kanan pada pasien ini.

Sebelum dilakukan operasi pasien di lakukan Six Minute Walk Tes untuk pra operasi dengan hasil $262 \mathrm{~m}$ dalam 6 menit. Pasien tidak dilakukan Faal paru pra operatif dikarenakan pasien mas ih dengan hemoptisis massif dan dikhawatirkan akan memicu hemoptisis yang lebih parah.

Terapi reseksi pada pembedahan tuberkulosis paru ada 4 cara: 1) Pneumonektomi; 2) Lobektomi; 3) Segmentektomi dan 4) Eksisi lokal. Lobektomi adalah prosedur pembedahan yang dilakukan untuk mengambil atau mengangkat salah satu lobus dari suatu organ. Bila lobus yang diangkat adalah lobus paru maka disebut lobektomi pulmoner. Keadaan darurat pembedahan paru dilakukan pada pasien: (I) hemoptisis berulang meskipun sudah diberikan tindakan yang memadai. (II) lokasi pendarahan yang sudah jelas; (III) memiliki fungsi paru yang memadai ${ }^{15}$

Tindakan bedah dapat menjadi pilihan dalam penatalaksanaan hemoptisis, namun hampir $50 \%$ dari penderita hemoptisis tidak dapat dilakukan operasi akibat fungsi jantung paru yang tidak memadai. Selain itu, angka mortalitas akibat operasi, terutama yang bersifat darurat, mencapai 23-50\%. Tindakan bedah seharusnya hanya dikerjakan pada penderita dalam keadaan darurat dimana fasilitas BAE tidak ada, secara teknik tidak mungkin dilakukan BAE (adanya arteri spinal), serta perdarahan aktif persisten setelah BAE. Reseksi paru (segmentektomi, lobektomi, pneumonektomi) dipertimbangkan untuk lesi fokal, terutama yang memiliki kecenderungan untuk mengalami perdarahan berulang (seperti mycetoma). Keuntungan harus dibandingkan dengan risiko komplikasi operasi. Komplikasi postoperasi antara lain perdarahan, empyema, infeksi paru, infeksi luka operasi, gagal napas, dan bronchopleural fistula ${ }^{15}$

Pada kasus ini pasien setelah dilakukan tindakan Lobektomi lobus superior paru kanan, perawatan 15 hari pasca operasi kondisi pasien membaik tanpa keluhan hemoptisis berulang lagi. Pasien disarankan rawat jalan dan melanjutkan pengobatan OAT sampai selesai

\section{KESIMPULAN}

Seorang Laki-laki 36 tahun datang dengan batuk berdarah berulang dan $\mathrm{Tb}$ paru dalam terapi OAT fase lanjutan. Pasien sudah kali sekian untuk perawatan di Rumah sakit dengan keluhan yang sama. Terapi konvesional untuk pengobatan hemoptisis berulang dianggap gagal kemudian disarankan terapi pembedahan untuk mengatasi masalah tersebut, setelah dilakukan lobektomi lobus superior paru kanan kondisi pasien membaik. Setelah 15 hari pasca operasi kondisi pasien membaik tanpa keluhan hemoptisis berulang.

\section{DAFTAR PUSTAKA}

1. Anonymous. Profil kesehatan Provinsi Jawa Timur 2015. Dinkes Jawa Timur. 2015.; 23-26

2. Weinberger SE, Lipson DA. Cough and hemoptysis. In: Fauci AS, Braunwald E, Kasper DL, et al., eds. Harrison's Principles of Internal Medicine. 17th New York, NY: McGraw-Hill; 2008:225-228.

3. Cahill BC, Ingbar DH. Massive hemoptysis. Assessment and management. Clin Chest Med 2012; 15: 147-67.

4. Corey R, Hla KM. Major and massive hemoptysis: reassessment of conservative management. Am J Med Sci 1997; 294: 301-9

5. Zhang Y, Chen C, and Jiang G. Surgery of massive hemoptysis in pulmonary tuberculosis: Immediate and long-term outcomes. The Journal of Thoracic and Cardiovascular Surgery.2014. Volume 148, Number 2

6. Conlan AA, Hurwitz SS, Krige L, Nicolaou N, Pool R. Massive hemoptysis. Review of 123 cases. J Thorac Cardiovasc Surg 1;85: 120-4.

7. Semih Halezeroğlu, Erdal Okur. Thoracic surgery for haemoptysis in the context of tuberculosis: what is the best management approach? J Thorac Dis 2014;6(3):182-185.

8. Azizollah Abbasi Dezfouli, Abolghasem Daneshvar Kakhki, Roya Farzanegan et all. Results 
of Lobectomy and Pneumonectomy in Pulmonary TB. Tanaffos 2005; 2(7): 33-39

9. Lee TW, Wan S, Choy DK, Chan M, Arifi A, Yim AP. Management of massive hemoptysis: a single institution experience. Ann Thorac Cardiovasc Surg 2000; 6: 232-5.

10. Kenneth L. Mattox, and Gene A. Guinn. Emergency Resection for Massive Hemoptysis. J. Thoruc.Curdiovusc. Surg.2012. 62:411.

11. Shouyong Tan, Danxiong Sun, Tiantuo Zhang et all. Risk Factors for Hemoptysis in Pulmonary Tuberculosis Patients from Southern China: A Retrospective Study. Journal of Tuberculosis Research, 2014, 2, 173-180

12. Liu SF, Lee TY, Wong SL, Lai YF, Lin AS. Transient cortical blindness: a complication of bronchial artery embolization. Respir Med 2012; 92:983-986.

13. Lordan JL, Gascoigne A, Corris PA. The pulmonary physician in critical care: assessment and management of massive hemoptysis. BMJ Thorax.2003:58: 814-9.
14. Spinu C, Gonzalez EC, Andreu M, Gallardo X, Duaso MM, Bustelo JC. (2013). Life threatening hemoptysis: role of MDCT angiography. European Society of Radiology. p.1-25.

15. Agmy GM, Wafy SM, Mohamed SA, Gad YA, Mustafa H, El-Aziz AE. Bronchial and nonbronchial systemic artery embolization in management of Hemoptysis: experience with 348 patients. ISRN VascularMedicine, 2013: 1-5.

16. Sopko DR, Smith TP. Bronchial artery embolization for hemoptysis. Seminar in Interventional Radiology.2011: 28: 42-62.

17. Sidhu M, Wieseler K, Burdick TR, Shaw DW. Bronchial artery embolization for hemoptysis. Seminar in Interventional Radiology.2003: 25(3): 310 